\title{
Modeling ripple oscillations in the hippocampus
}

\author{
José R Donoso ${ }^{1,2^{*}}$, Nikolay Chenkov², Richard Kempter ${ }^{1,2}$ \\ From Twenty Second Annual Computational Neuroscience Meeting: CNS*2013 \\ Paris, France. 13-18 July 2013
}

Sharp wave-ripples (SWRs) are highly synchronous network events displayed by the mammalian hippocampus during slow-wave sleep and immobile resting periods. A SWR event ( $100 \mathrm{~ms}$ duration) is characterized by fast network oscillations ( $200 \mathrm{~Hz}$ "ripples") superimposed by a sharp wave, which is a large-amplitude, low-frequency $(<10 \mathrm{~Hz})$ signature in the local field potential of the hippocampal CA1 region. Such events are involved in memory consolidation. Understanding the mechanisms that give rise to SWRs can help us to gain insights on the computations being implemented during memory consolidation.

Despite a large amount of electrophysiological data on SWRs in vivo (e.g. [1]) and in vitro (e.g. [2-4]) and many computational models (e.g. [5] and [6]), the basic mechanisms behind SWR generation remain elusive. Regarding the origin of the high-frequency ripple component during SWRs, two (not mutually exclusive) generative mechanisms have been proposed: First, a rhythmic output of a network of principal cells coupled by gap junctions, presumably between axons of pyramidal cells [5]. Second, an interneuron network coupled by chemical synapses that modulates the firing of pyramidal cells [6]. Modeling studies showed that both mechanisms can give rise to a prominent ripple component in the $200 \mathrm{~Hz}$ range. These two mechanisms could not only coexist but also be differentially expressed during SWR generation.

Here we explore the oscillatory behavior of an in-silico model of a CA1 interneuron network to mimic in-vitro recordings from CA1 slices in which excitatory synaptic transmission is blocked and SWRs are induced by application of brief potassium puffs, which transiently excite neurons [3]. In such a preparation, the two proposed ripple generating mechanisms are decoupled and can be

\footnotetext{
* Correspondence: jose.donoso@bccn-berlin.de

'Bernstein Center for Computational Neuroscience Berlin, 10115 Berlin, Germany

Full list of author information is available at the end of the article
}

studied in isolation. Focusing on a model of a random interneuron network, we found that the power of ripple oscillations is stable for a wide range of the strength of the recurrent inhibitory coupling. A reduction of inhibitory conductance leads to a slight increase in network frequency, which is in line with [4]. Furthermore, larger reductions of inhibitory coupling leads to an abrupt decay of ripple power (see also [3]). Thus, some of the phenomenology of SWRs in vitro can be described in terms of chemical synaptic inhibition.

\section{Acknowledgements}

Supported by BMBF grants no. 01GQ1001A and 01GQ0972 and by the DFG (SFB 618).

\section{Author details}

${ }^{1}$ Bernstein Center for Computational Neuroscience Berlin, 10115 Berlin, Germany. ${ }^{2}$ Institute for Theoretical Biology, Humboldt-Universität zu Berlin, 10115 Berlin, Germany.

Published: 8 July 2013

\section{References}

1. Ylinen A, Bragin A, Nadasdy Z, Szabo I, Sik A, Buzsáki G: Sharp waveassociated high-frequency oscillation $(200 \mathrm{~Hz})$ in the intact hippocampus: network and intracellular mechanisms. J Neurosci 1995, 15:30-46.

2. Csicsvari J, Hirase H, Czurkó A, Mamiya A, Buzsáki G: Fast network oscillations in the hippocampal CA1 region of the behaving rat. J Neurosci 1999, 19:RC20.

3. Maier N, Tejero-Cantero A, Dorrn A, Winterer J, Beed P, Morris G, Kempter R, Poulet J, Leibold C, Schmitz D: Coherent phasic excitation during hippocampal ripples. Neuron 2011, 72:137-152.

4. Nimmrich V, Maier N, Schmitz D, Draguhn A: Induced sharp wave-ripple complexes in the absence of synaptic inhibition in mouse hippocampal slices. J Physiol 2005, 563(3):663-670.

5. Behrens CJ, van den Boom LP, Heinemann U: Effects of the GABA receptor antagonists bicuculline and gabazine on stimulus-induced sharp-wave ripple complexes in adult rat hippocampus in vitro. Eur J Neurosci 2007, 25:2170-2181.

6. Traub RD, Schmitz D, Jeffreys JG, Draguhn A: High-frequency population oscillations are predicted to occur in hippocampal pyramidal neuronal networks interconnected by axo-axonal gap junctions. Neuroscience 1999, 92:407-426. 
7. Brunel $\mathrm{N}$, Wang $\mathrm{XJ}$ : What determines the frequency of fast network oscillations with irregular neural discharges? I. Synaptic dynamics and excitation-inhibition balance. J Neurophysiol 2003, 90:415-430.

doi:10.1186/1471-2202-14-S1-P208

Cite this article as: Donoso et al:: Modeling ripple oscillations in the hippocampus. BMC Neuroscience 2013 14(Suppl 1):P208.

Submit your next manuscript to BioMed Central and take full advantage of:

- Convenient online submission

- Thorough peer review

- No space constraints or color figure charges

- Immediate publication on acceptance

- Inclusion in PubMed, CAS, Scopus and Google Scholar

- Research which is freely available for redistribution

Submit your manuscript at www.biomedcentral.com/submit
C Biomed Central 